\title{
Bar Soap Dosage Form
}

National Cancer Institute

\section{Source}

National Cancer Institute. Bar Soap Dosage Form. NCI Thesaurus. Code C91137.

A solid in the shape of a bar composed of active and/or inert ing redient(s) in an anionic surfactant, for cleansing. 